\title{
Competition between the introduced polychaete Marenzelleria sp. and the native amphipod Monoporeia affinis in Baltic soft bottoms
}

\author{
Rasmus Neideman*, Johan Wenngren, Emil Ólafsson \\ Department of Zoology, Stockholm University, 10691 Stockholm, Sweden
}

\begin{abstract}
The North American spionid polychaete Marenzelleria cf. viridis was reported from the Baltic Sea for the first time in 1985. The species has spread rapidly and now dominates many softbottom communities, where it dwells in burrows down to $30 \mathrm{~cm}$ deep in the sediment. In the Baltic Sea, below $10 \mathrm{~m}$ water depth, the macrobenthic community is composed of only a handful of species, among which the amphipod Monoporeia affinis is a key member. This species is highly mobile; it swims actively at night but remains burrowed in the sediment during the day. Due to similarities in feeding mode and sympatric occurrence, the polychaete may compete with the amphipod for both food and space. One plausible outcome of interactions between the 2 species is that the amphipod, the more mobile species, would avoid areas where the more sessile polychaete is present in high numbers. In the laboratory, we tested the hypothesis that, if given the choice, the amphipod avoids burrowing in sediment with high polychaete abundances. The amphipod burrowed in significantly lower numbers in patches with high polychaete abundance compared to those with lower abundance. Also, plastic tubes mimicking polychaete body structure were not avoided by the amphipods, indicating that the physical tube structure of the polychaetes does not explain the amphipod's choice of burrowing site. Furthermore, the amphipod did not increase or prolong swimming activities as a function of higher worm density, indicating that increased swimming activity over dense polychaete patches and subsequent migration away from them is not a likely explaination of why this amphipod burrow less frequently in patches of high polychaete abundance.
\end{abstract}

KEY WORDS: Alien species · Native species - Behaviour - Interference $\cdot$ Competition $\cdot$ Benthos · Baltic Sea $\cdot$ Laboratory experiment

Resale or republication not permitted without written consent of the publisher

\section{INTRODUCTION}

The field of invasion-ecology was introduced by Elton (1958) and has since then gained increasing attention, especially for commercially important terrestrial habitats.

During the last 2 centuries, the rate of species introductions into marine and brackish-water ecosystems has increased exponentially (Gollasch 1996, Cohen \& Carlton 1998, Leppaekoski \& Olenin 2000a, Ruiz et al. 2000). In San Francisco Bay, for example, over 230 introduced species have been reported, and these now constitute between 40 and $100 \%$ of the most abundant species (Cohen \& Carlton 1998). Over 100 species have been transferred to the Baltic Sea area during the same period, and between 3 and $29 \%$ of all Baltic Sea species are considered to be of recent $(<200 \mathrm{yr})$ foreign origin (Leppaekoski \& Olenin 2000a). Some of the introduced species have inhabited the native community in relatively low numbers with no apparent effects, while others have quickly reached high population densities and sometimes dominate the community, seemingly at the expense of native species (Cohen \& Carlton 1998, Leppaekoski \& Olenin 2000b).

A large amount of the aquatic invasion literature deals with patterns, processes and theories regarding when, where and which species will invade a particular native community. Most of the studies have been descriptive, and many of the experimental studies have focused on effects of introduced predators (Ler- 
oux et al. 1990, Dick et al. 1999, 2002, Hill \& Lodge 1999, Dick \& Platvoet 2000, Grosholz et al. 2000, Brousseau et al. 2001, Nystrom et al. 2001, Dick et al. 2002, Holloway \& Keough 2002, Jensen et al. 2002, Lohrer \& Whitlatch 2002, Walton et al. 2002, Ross et al. 2003, Stenroth \& Nystrom 2003).

Apart from 2 studies indicating that, despite competitors, some invaders succeed through superior conversion efficiency (Hill et al. 1993, Byers 2000), little experimental data is available on competition between introduced and native animals. A few studies have demonstrated various forms of interference competition (Race 1982, Marchetti 1999, McDonald et al. 2001, 2001, Janssen \& Jude 2001, Usio et al. 2001) and some have shown increased mortality or reduced growth in native species in the presence of an invader (Kotta et al. 2001, Kotta \& Ólafsson 2003).

One recent, successful invader in the Baltic Sea is the North American polychaete Marenzelleria cf. viridis (Verrill, 1873) (Polychaeta: Spionidae), which was observed in the southern Baltic Sea for the first time in 1985, and was probably introduced as pelagic larvae with ballast water (Bick \& Burckhardt 1989). Subsequently, it has spread more than $1000 \mathrm{~km}$, as far as the oligohaline Gulf of Bothnia (Stigzelius et al. 1997, Leonardsson 2000) and Bothnian Bay (Leonardsson \& Karlsson 2002).

Marenzelleria cf. viridis lives in tubes extending about 10 to $35 \mathrm{~cm}$ into the sediment (Zettler et al. 1994). It spends most of its time in its tube, but partially emerges when feeding from the sediment surface or suspension-feeding from the water column (Dauer et al. 1981, Bock \& Miller 1999). Occasionally it has also been observed swimming during early spring (a behavior that has been related to reproduction: Dauer et al. 1980, Russell 1995), and it has been found in the stomachs of several fish species (Winkler \& Debus 1997). Marenzelleria cf. viridis prefers sandy sediment, but seems to settle in all sediments with low clay content (Dauer et al. 1981, Gruszka 1999) at water depths ranging from <1 to $90 \mathrm{~m}$ (Lagzdins \& Pallo 1994, Kube et al. 1996).

One of the most ecologically important and dominant native species in the Baltic Sea benthic community between 10 and about $80 \mathrm{~m}$ is the deposit-feeding amphipod Monoporeia affinis (Lindström) (Ankar \& Elmgren 1976, Ankar 1977, Laine et al. 1997). It is a benthic species inhabiting the top $5 \mathrm{~cm}$ of the sediment (Byren et al. 2002) that displays nocturnal swimming activity in the water column (Donner \& Lindström 1980). The reasons for its nocturnal migration pattern are not known, but have been suggested to be related to predator avoidance during moulting (Cederwall 1990), reproduction and when searching for suitable substrates (Donner et al. 1987).
Marenzelleria cf. viridis was shown to reduce growth in Monoporeia affinis in a laboratory experiment by Kotta \& Ólafsson (2003). It is likely that the 2 species compete for food, as $M$. cf. viridis feeds mainly on surface deposits of material from primary production (Dauer et al. 1981), and M. affinis seems to rely mainly on the same food source and, to a lesser extent on bacteria involved in the degradation of primary producers (Aljetlawi et al. 2000). M. affinis has been shown to be food-limited for most of the year (Elmgren et al. 2001) and has been observed to avoid patches of low and also of extremely high food levels (J. Wenngren pers. obs.). Another possibility is that the 2 species minimise competition by avoiding patches of high competitor abundance. As $M$. affinis is the more mobile of the 2 species, it is probable that it avoids burrowing in patches with high densities of $M$. cf. viridis. We tested this hypothesis with an experiment in which $M$. affinis could choose between sediment patches containing different densities of $M$. cf. viridis. Our results showed that $M$. affinis clearly avoids sediment with high densities of this polychaete and we therefore ran a further experiment, using plastic worm mimics to determine if mere physical presence would explain the results. In a third experiment, we tested the null-hypothesis that the worms have no effect on the diurnal swimming pattern of the amphipods.

\section{MATERIALS AND METHODS}

Expt 1: Choice experiment with live polychaetes. This and the following experiments were performed in a thermo-constant room at ambient sea-temperature $\pm 2^{\circ} \mathrm{C}$. We used a large plastic container (length/ width/height $=80 / 60 / 30 \mathrm{~cm}$; Fig. 1) holding 48 smaller jars (380 ml, $53 \mathrm{~cm}^{2}$ surface area) filled with sieved natural sediment and worms at 6 different densities $(0,2,4,6,10$ or 20 individuals per sediment jar, corresponding to $0,380,750,1130,1890$ and 3780 individuals $\mathrm{m}^{-2}$ ) replicated 8 times in a randomized block design (Fig. 1). Marenzelleria cf. viridis was collected on 3 to 4 May 2001 at 0.5 to $0.8 \mathrm{~m}$ depth from a sandy beach about $40 \mathrm{~km}$ southwest of Stockholm $\left(59^{\circ} 2^{\prime} 29^{\prime \prime} \mathrm{N}\right.$, $\left.17^{\circ} 41^{\prime} 45^{\prime \prime} \mathrm{E}\right)$. The sand was sieved through a $1 \mathrm{~mm}$ screen, and the worms were removed and stored in aerated brackish water without food until the experiment 4 d later. Amphipods were collected from a $30 \mathrm{~m}$ deep station about $2 \mathrm{~km}$ west of Askö laboratory $\left(59^{\circ} 49^{\prime} 29^{\prime \prime} \mathrm{N}, 17^{\circ} 46^{\prime} 12^{\prime \prime} \mathrm{E}\right)$ at the beginning of April by sampling sediment with a benthic sled (Blomqvist \& Lundgren 1996). The sediment was sieved through a $1 \mathrm{~mm}$ screen and 1+ year-class individuals were isolated. Additionally, fine sediment for the experimental units was taken from the same area with a van Veen 


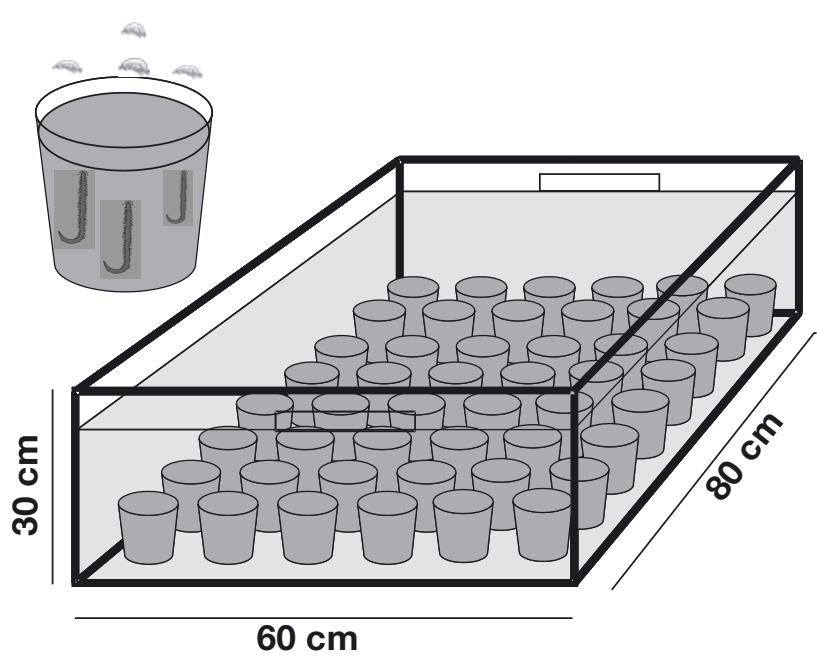

Fig. 1. Design of the choice experiments

grab and, before addition to the jars, sieved through a $0.5 \mathrm{~mm}$ aperture sieve to remove all macrofauna and homogenised by stirring.

The worms were added to the sediment surface of the jars, and the container was then filled with water and left overnight. Worms that had not dug into the sediment by the following morning were replaced (a total of 5 individuals). The worms were allowed to acclimatise with a continuous filtered brackish water supply of about $30 \mathrm{l} \mathrm{h}^{-1}$. After about $1 \mathrm{wk}$, the water flow was shut off and 480 individuals of Monoporeia affinis were added to the container, corresponding to about 2000 individuals $\mathrm{m}^{-2}$ sediment surface, a normal field density in the 10 to $40 \mathrm{~m}$ depth range in this area (Ankar \& Elmgren 1976).

The amphipods were left for $4 \mathrm{~d}$ in dim light to establish diurnal burrowing and swimming activities. At noon on the 4th day, when practically all amphipods had burrowed into the sediment, the water level was lowered to isolate the jars from each other. The contents of the jars were sieved through a $1 \mathrm{~mm}$ sieve and all amphipods counted. A 1-way ANOVA was performed on transformed data $(\ln [x+2])$, Bartlett's chi-square $=$ 9.3, $p=0.10$ ) to ensure homogeneous variance. The data were also analysed for potential block-effects using 1-way ANOVA, as the data set as a whole did not meet the criteria for a 2-way ANOVA design.

Expt 2: Choice experiment with physical hindrance. This experiment was performed at the same time of the year and in the same way as Expt 1, but in the following year and using vertical PTFE (polytetrafluoroethylene) tubes as worm mimics. The tubes were placed vertically and randomly in the jars, flush with the sediment surface, and were of similar dimensions (length $50 \mathrm{~mm}$, diameter $1.3 \mathrm{~mm}$ ) to the worm tubes.
We used the same densities as for the worms. Amphipods $(1+$ year class) and sediment were collected from a station about $5 \mathrm{~km}$ east of Askö $\left(58^{\circ} 49^{\prime} 28^{\prime \prime} \mathrm{N}\right.$, $17^{\circ} 47^{\prime} 13^{\prime \prime}$ E) because of unusually low amphipod densities at the previously sampled station. The analysis was performed on transformed amphipod densities $(\ln [x+2])$, Bartlett's chi-square 3.33, p = 0.65). The data were also analysed for potential block-effects using 1-way ANOVA, as the data set as a whole did not meet the criteria for a 2-way ANOVA design.

Expt 3: Swimming experiment. This experiment determined whether the presence of the worms resulted in the amphipods spending more time swimming in the water column by counting the number of swimming amphipods in jars with different worm densities. Counting was performed once every hour for $24 \mathrm{~h}$. The experiment was repeated twice, first with amphipods acclimatised to worms for $1 \mathrm{wk}$ before counting, and then with amphipods with no previous acclimatisation to worms in the laboratory. The jars (diameter $9.5 \mathrm{~cm}$, height $22 \mathrm{~cm}$ ) contained 0,4 or 11 worms and 12 0+ amphipods (corresponding to 0, 700 and 1900 worms and 2100 amphipods $\mathrm{m}^{-2}$ ) and each treatment was replicated 5 times. Each jar was connected to a brackish water supply and a $5 \mathrm{~mm}$ outflow pipe covered with a $1 \mathrm{~mm}$ meshed nylon net to prevent the amphipods from escaping. The experiment was carried out in November 2002 in a 8:16 h light:dark regime of weak green light. Since the eye of Monoporeia affinis is sensitive mainly to green light (550 nm) (Donner 1971), red light was used during counting to disturb the amphipods as little as possible.

Amphipods and sediment were collected at the same location as in the second choice experiment (Expt 2) $2 \mathrm{~d}$ before the swimming experiment was set up, and were stored in aerated brackish water in a thermo-constant room. The sediment was treated as in the 2 previous experiments. The worms were collected from the same location as in the first choice experiment (Expt 1) and stored in aerated brackish water for $5 \mathrm{~d}$ before the experiment was set up.

The jars were supplied with a continuous brackish water flow during acclimatisation. The water was shut off just before counting began. After the first $24 \mathrm{~h}$ counts, the microcosms were again supplied with flowing brackish water, and the outflow nets were removed for $1 \mathrm{wk}$ to allow the amphipods to escape before new amphipods were added for a second counting. Thus, the same worms were used in both experiments. A net placed at the end of the whole set-up trapped the escaping amphipods, allowing us to determine when the majority had escaped (all but 5 individuals). At the end of the second experimental run, the sediment from each jar was sieved and the worms were counted. 


\section{RESULTS}

\section{Expt 1: Choice experiment with live polychaetes}

The number of amphipods in the jars differed significantly among treatments (ANOVA, p $<0.001$; Table 1). Monoporeia affinis was present in higher numbers in sediment jars with $0,2,4$ or 6 individuals of Marenzelleria cf. viridis than in sediment jars with 10 and 20 individuals (Tukey's HSD, p < 0,01, Fig. 2). There was no significant difference among blocks (ANOVA, $\mathrm{p}=0.67$ ) (Table 1).

Loss caused by handling and mortality among worms and amphipods was about 15 and $6 \%$ respectively. Some worms moved between jars during the experiment: 3 worms were found in different 0 treatment jars after the experiment, and in 3 other lowdensity jars the number of worms had also increased by 1 per jar. The average number of worms decreased during the experiment in all but the 0 treatment. The final average number of worms in the 6 treatments was $0.4,1.6,3.4,5,9$ and 16.4 respectively.

\section{Expt 2: Choice experiment with physical hindrance}

There was no significant difference in amphipod densities among the treatments (ANOVA, p $=0.92$, Fig. 3) but there was a significant block-effect (ANOVA, $\mathrm{p}<0.001$; Table 1). Mortality or loss of amphipods was about the same as in Expt 1 (4\%).

\section{Expt 3: Swimming experiment}

There was no visible difference in swimming activity between treatments regardless of whether or not the

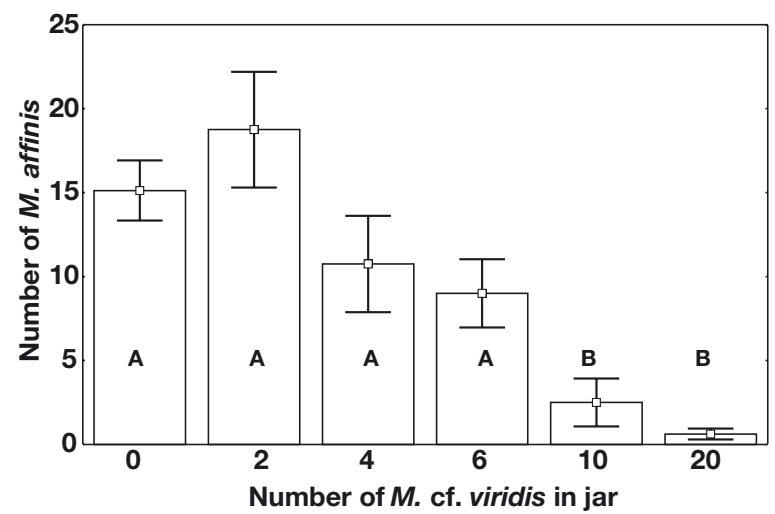

Fig. 2. Average number of Monoporeia affinis recovered in jars with different numbers of Marenzelleria cf. viridis $(\mathrm{n}=8, y$-bars indicating $\pm \mathrm{SE}$ ). Common letters indicate homogenous groups
Table 1. ANOVA of choice experiments

\begin{tabular}{|lcccc}
\hline Expt & Source of variation & df & $F$ & $\mathrm{p}$ \\
\hline Avoidance of worms & Block & 7 & 0.706 & 0.67 \\
$(1)$ & Treatment & 5 & 20.84 & $<0.001$ \\
Avoidance of tubes & Block & 7 & 6.525 & $<0.001$ \\
$(2)$ & Treatment & 5 & 0.282 & 0.92 \\
\hline
\end{tabular}

amphipods had been acclimatised to the polychaetes (Fig. 4). The loss of worms was between 0 and $73 \%$ (mean $32.5 \%, \mathrm{SD}=25.4$ ) but there was no significant difference between treatments. Only 1 worm was found in the net trap at the end of the set-up after exchange of the amphipods, indicating that mortality was the main reason for the low number of worms recovered at the termination of the experiment

\section{DISCUSSION}

It is clear from our results that Monoporeia affinis avoids burrowing in patches of high Marenzelleria cf. viridis abundance, at least under laboratory conditions. The amphipods did not respond to plastic tubes in the same way as to worms, and thus mere physical hindrance is an unlikely explanation. This result was not surprising, since field sediment usually contains a large number of particles similar in size to the worms. The amphipods are thus accustomed to contact with large objects in the sediment. This does, however, not rule out interference as the most likely explanation for the results in the first experiment, since the amphipods may still sense and react to both chemical and/or tactile signals from the worms.

Chemical substances involved in communication between interacting species are believed to be an

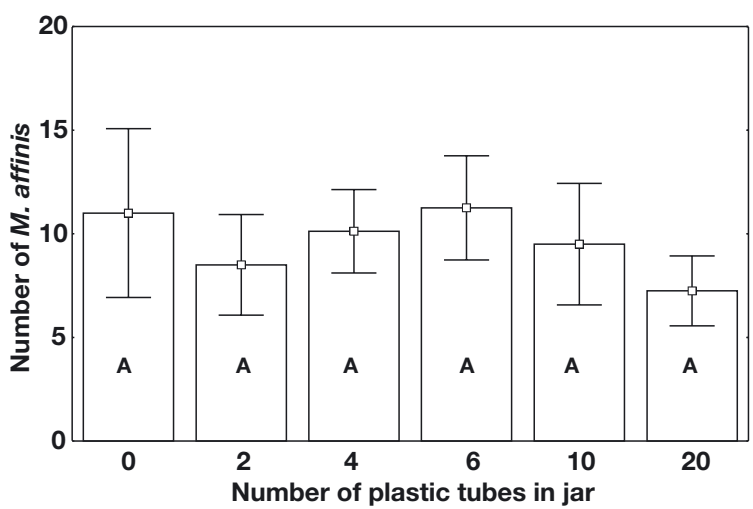

Fig. 3. Average number of Monoporeia affinis recovered in jars with different numbers of plastic tubes $(n=8, y$-bars indicating $\pm \mathrm{SE}$ ). Common letters indicate homogenous groups 


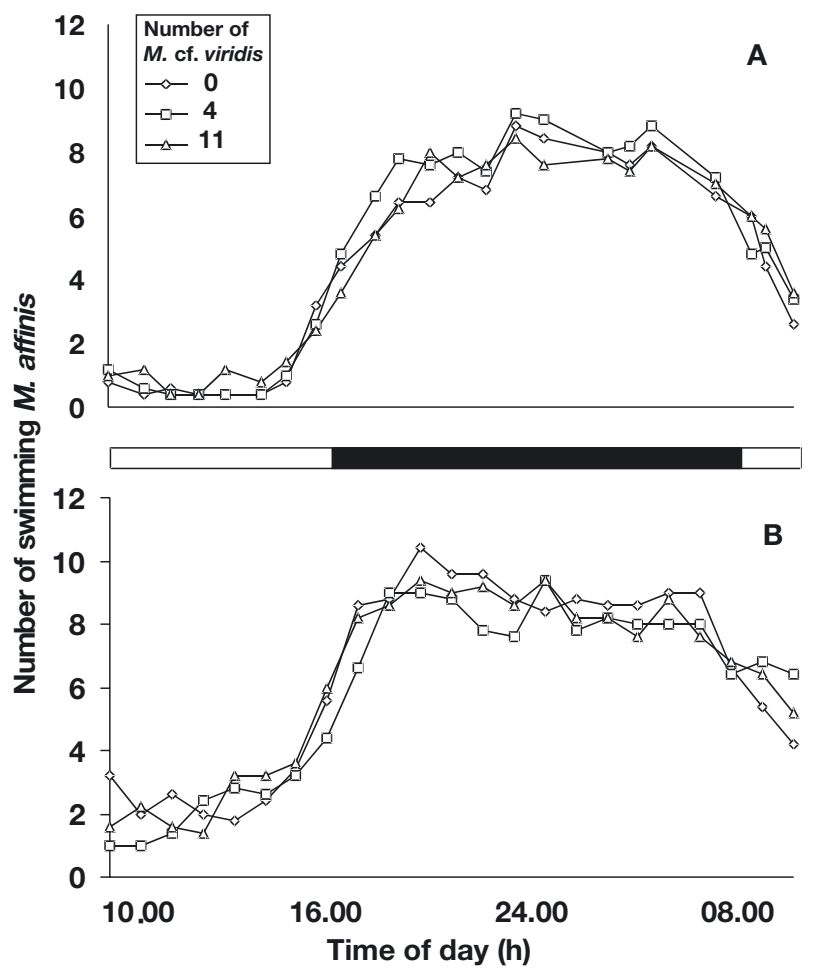

Fig. 4. Monoporeia affinis and Marenzelleria cf. viridis. Average number of swimming $M$. affinis in jars containing 3 densities of $M$. cf. viridis during $24 \mathrm{~h}(\mathrm{n}=5)$. M. affinis (A) acclimatised and (B) not acclimatised to $M$. cf. viridis

important feature in interference competition and predation among benthic invertebrates (Woodin 1991, McClintock \& Baker 1997). Marenzelleria cf. viridis is known to produce at least 1 chlorinated compound that could have such effect (Fielman et al. 1999). The amphipods have well-developed chemical receptors (Hallberg et al. 1997), which could conceivably allow them to sense the worms and thereby avoid worm encounter. Taking into account that both species are newly sympatric in distribution, such a mechanism is probably rather general in function. A generality of response is also supported by our observations that Monoporeia affinis avoids burrowing in sediments containing high densities of the Baltic clam Macoma balthica (L) (authors' pers. obs).

Jensen \& André (1993) found that the shallow-water amphipods Corophium volutator (Pallas) and C. araneum (Crawford) avoided the polychaete Nereis diversicolor (Müller) in experimental conditions. They suggested competition by interference as an explanation for the amphipods' migration away from the polychaete. $C$. volutator has also been shown to migrate away from mechanically disturbed sediment (Ronn et al. 1988).

Other explanations concerning exploitation of resources are also possible. If, for example, Marenzel- leria cf. viridis depletes the available food from the sediment surface, Monoporeia affinis could migrate away to other areas with presumably better conditions. $M$. affinis have earlier been shown to choose actively among different food levels (Wenngren et al. 2003). We did not investigate the chlorophyll concentration or organic content in the sediment, but as the deposition layer on the surface was evenly mixed throughout the whole sediment volume during preparation, we assume that the food levels were comparatively low. Therefore, it is unlikely that $M$. cf. viridis significantly affected food availability for the amphipods at such low levels during the short experimental period. Similar results were obtained by DeWitt \& Levinton (1985) investigating the distribution of the amphipod Microdeutopus gryllotalpa (Costa) in response to the mud snail Ilyanassa obsoleta (Say) over approximately the same time span. They concluded that food exploitation did not explain amphipod distribution, as they found no difference in chlorophyll concentration between the different treatments.

Monoporeia affinis is very sensitive to hypoxia and anoxia (Modig \& Ólafsson 1998), and has been shown to avoid patches of high sulphide concentration and low oxygen concentration when given the choice of more favourable areas (Ólafsson \& Limén 2002). Marenzelleria cf. viridis appears to be less sensitive to hypoxia owing to its ability for anaerobic energy production (Schiedek 1997). It has also been reported that $M$. affinis increases swimming frequency (but decreases swimming duration) at low oxygen levels (Johansson 1997). Had the oxygen levels at surface of sediments containing high densities of polychaetes been critically low during Expt 1, the amphipods would have swum away from those jars and moved to nearby jars with presumably better conditions. However, Expt 3 did not reveal increased or prolonged swimming of amphipods over jars with high worm densities, making this explanation unlikely.

Although no worms were observed to swim in the water above the jars in Expt 1, some individuals must have swum up from the sediment and actively moved to a nearby jar. This observation, together with our observations (J. Wenngren pers. obs.) of pelagic feeding fishes with stomachs filled with Marenzelleria cf. viridis during winter, supports the idea that adult $M$. cf. viridis swims up into the water column to reach new habitats (Kube et al. 1996).

This study has demonstrated that an invader can affect the distribution patterns of a keystone native species. This specific interaction has not been documented in the field, where Marenzelleria cf. viridis densities in our areas do not exceed about 700 individuals $\mathrm{m}^{-2}$, and it is not clear how important it is in relation to other factors regulating Monoporeia affinis 
population dynamics. $M$. affinis are known to vary considerably in abundance between years, but in the Gulf of Riga, a massive population decrease coincided with the invasion of $M$. cf. viridis (Cederwall et al. 1999), possibly facilitating the invasion process. If the behaviour shown by $M$. affinis in our experiment reflects that in the field, it could decrease the overlap in the distributions of these 2 species.

Acknowledgements. We would like to thank the director of the Askö field station, B. Ganning, for providing laboratory space and financial support, the technical staff at Askö for various kinds of help, and L. Arroyo who provided helpful comments on the manuscript.

\section{LITERATURE CITED}

Aljetlawi AA, Albertsson J, Leonardsson K (2000) Effect of food and sediment pre-treatment in experiments with a deposit-feeding amphipod, Monoporeia affinis. J Exp Mar Biol Ecol 249:263-280

Ankar S (1977) The soft bottom ecosystem of the northern Baltic proper with special reference to the macrofauna. Contrib Askö Lab Univ Stock 19:1-62

Ankar S, Elmgren R (1976) The benthic macro- and meiofauna of the Askö-Landsort area (northern Baltic proper). A stratified random sampling survey. Contrib Askö Lab Univ Stock 11:1-115

Bick A, Burckhardt R (1989) Erstnachweis von Marenzelleria viridis (Polychaeta, Spionidae) für den Ostseeraum, mit einem Bestimmungsschlüssel der Spioniden der Ostsee. Mitt Zool Mus Berl 65:237-247

Blomqvist S, Lundgren L (1996) A benthic sled for sampling soft bottoms. Helgol Meeresunters 50:453-456

Bock MJ, Miller DC (1999) Particle selectivity, gut volume, and the response to a step change in diet for depositfeeding polychaetes. Limnol Oceanogr 44:1132-1138

Brousseau DJ, Filipowicz A, Baglivo JA (2001) Laboratory investigations of the effects of predator sex and size on prey selection by the Asian crab, Hemigrapsus sanguineus. J Exp Mar Biol Ecol 262:199-210

Byers JE (2000) Competition between two estuarine snails: implications for invasions of exotic species. Ecology 81: 1225-1239

Byren L, Ejdung G, Elmgren R (2002) Comparing rate and depth of feeding in benthic deposit-feeders: a test on two amphipods, Monoporeia affinis (Lindström) and Pontoporeia femorata (Kroeyer). J Exp Mar Biol Ecol 281:1-2

Cederwall H (1990) Diurnal pelagic swimming activity of Pontoporeia-a waste of energy? Ann Zool Fenn 27:307

Cederwall H, Jermakovs V, Lagzdins G (1999) Long-term changes in the soft-bottom macrofauna of the Gulf of Riga. ICES J Mar Sci 56:41-48

Cohen AN, Carlton JT (1998) Accelerating invasion rate in a highly invaded estuary. Science 279:555-558

Dauer DM, Ewing RM, Tourtellotte GH, Barker HR Jr (1980) Nocturnal swimming of Scolecolepides viridis (Polychaeta: Spionidae). Estuaries 3:148-149

Dauer DM, Maybury CA, Ewing RM (1981) Feeding behavior and general ecology of several spionid polychaetes from the Chesapeake Bay. J Exp Mar Biol Ecol 54:21-38

DeWitt TH, Levinton JS (1985) Disturbance, emigration, and refugia: how the mud snail, Ilyanassa obsoleta (Say), affects the habitat distribution of an epifaunal amphipod, Microdeutopus gryllotalpa (Costa). J Exp Mar Biol Ecol 92: 97-113

Dick JTA, Platvoet D (2000) Invading predatory crustacean Dikerogammarus villosus eliminates both native and exotic species. Proc R Soc Lond B 267:977-983

Dick JTA, Montgomery WI, Elwood RW (1999) Intraguild predation may explain an amphipod replacement: evidence from laboratory populations. J Zool 249:463-468

Dick JTA, Platvoet D, Kelly DW (2002) Predatory impact of the freshwater invader Dikerogammarus villosus (Crustacea: Amphipoda). Can J Fish Aquat Sci 59:1078-1084

Donner KO (1971) On vision in Pontoporeia affinis and $P$. femorata (Crustacea, Amphipoda). Comment Biol Soc Sci Fenn 41:1-17

Donner KO, Lindström M (1980) Sensitivity to light and circadian activity of Pontoporeia affinis (Crustacea, Amphipoda). Ann Zool Fenn 17:203-212

Donner KO, Lindström A, Lindström M (1987) Seasonal variation in the vertical migration of Pontoporeia affinis (Crustacea, Amphipoda). Ann Zool Fenn 24:305-313

Elmgren R, Ejdung G, Ankar S (2001) Intraspecific food competition in the deposit-feeding amphipod Monoporeia affinis - a laboratory study. Mar Ecol Prog Ser 210:185-193

Elton CS (1958) The ecology of invasions by animals and plants. Chapman \& Hall, London

Fielman KT, Woodin SA, Walla MD, Lincoln DE (1999) Widespread occurrence of natural halogenated organics among temperate marine infauna. Mar Ecol Prog Ser 181: $1-12$

Gollasch S (1996) Untersuchungen des Arteintrages durch den internationalen Schiffsverkehr unter besonderer Berücksichtigung nichtheimischer Arten. PhD thesis, Hamburg University

Grosholz ED, Ruiz GM, Dean CA, Shirley KA, Maron JL, Connors PG (2000) The impacts of a nonindigenous marine predator in a California bay. Ecology 81:1206-1224

Gruszka P (1999) The River Odra estuary as a gateway for alien species immigration to the Baltic Sea basin. Acta Hydrochim Hydrobiol 27:374-382

Hallberg E, Johansson KUI, Wallen R (1997) Olfactory sensilla in crustaceans: morphology, sexual dimorphism, and distribution patterns. Int $J$ Insect Morphol Embryol 26: $173-180$

Hill AM, Lodge DM (1999) Replacement of resident crayfishes by an exotic crayfish: the roles of competition and predation. Ecol Appl 9:678-690

Hill AM, Sinars DM, Lodge DM (1993) Invasion of an occupied niche by the crayfish Orconectes rusticus: potential importance of growth and mortality. Oecologia 94:303-306

Holloway MG, Keough MJ (2002) An introduced polychaete affects recruitment and larval abundance of sessile invertebrates. Ecol Appl 12:1803-1823

Janssen J, Jude DJ (2001) Recruitment failure of mottled sculpin Cottus bairdi in Calumet Harbor, Southern Lake Michigan, induced by the newly introduced round goby Neogobius melanostomus. J Gt Lakes Res 27:319-328

Jensen GC, McDonald PS, Armstrong DA (2002) East meets west: competitive interactions between green crab Carcinus maenas, and native and introduced shore crab Hemigrapsus spp. Mar Ecol Prog Ser 225:251-262

Jensen KT, André C (1993) Field and laboratory experiments on interactions among an infaunal polychaete, Nereis diversicolor, and 2 amphipods, Corophium volutator and $C$. arenarium-effects on survival, recruitment and migration. J Exp Mar Biol Ecol 168:259-278

Johansson B (1997) Behavioural response to gradually declin- 
ing oxygen concentration by Baltic Sea macrobenthic crustaceans. Mar Biol 129:71-78

Kotta J, Ólafsson E (2003) Competition for food between the introduced exotic polychaete Marenzelleria viridis and the resident native amphipod Monoporeia affinis in the Baltic Sea. J Sea Res 50:27-35

Kotta J, Orav H, Sandberg-Kilpi E (2001) Ecological consequence of the introduction of the polychaete Marenzelleria cf. viridis into a shallow-water biotope of the northern Baltic Sea. J Sea Res 46:273-280

Kube J, Zettler ML, Gosselck F, Ossig S, Powilleit M (1996) Distribution of Marenzelleria viridis (Polychaeta: Spionidae) in the southwestern Baltic Sea in 1993/94 — ten years after introduction. Sarsia 81:131-142

Lagzdins G, Pallo P (1994) Marenzelleria viridis (Verrill) (Polychaeta, Spionidae) - a new species for the Gulf of Riga. Proc Est Acad Sci Biol 43:184-188

Laine AO, Sandler H, Andersin AB, Stigzelius J (1997) Longterm changes of macrozoobenthos in the eastern Gotland Basin and the Gulf of Finland (Baltic Sea) in relation to the hydrographical regime. J Sea Res 38:1-2

Leonardsson K (2000) Soft bottom fauna. In: Wiklund K (ed) Bothnian Bay, UMF annual report from the marine environment-monitoring programme 2000 (in Swedish). Print \& Media, Umeå University, p 12-14

Leonardsson K, Karlsson A (2002) Soft bottom fauna. In: Wiklund $\mathrm{K}$ (ed) Bothnian Bay, UMF annual report from the marine environment-monitoring programme 2002 (in Swedish). Print \& Media, Umeå University, p 13-16

Leppaekoski E, Olenin S (2000a) Non-native species and rates of spread: lessons from the brackish Baltic Sea. Biol Invasions 2:151-163

Leppaekoski E, Olenin S (2000b) Xenodiversity of the European brackish water seas: the North American contribution. Massachusetts Institute of Technology, Cambridge MA

Leroux PJ, Branch GM, Joska MAP (1990) On the distribution, diet and possible impact of the invasive European shore crab Carcinus maenas (L.) along the South-African coast. S Afr J Mar Sci 9:85-93

Lohrer AM, Whitlatch RB (2002) Relative impacts of two exotic brachyuran species on blue mussel populations in Long Island Sound. Mar Ecol Prog Ser 227:135-144

Marchetti MP (1999) An experimental study of competition between the native Sacramento perch (Archoplites interruptus) and introduced bluegill (Lepomis macrochirus). Biol Invasions 1:55-65

McClintock JB, Baker BJ (1997) A review of the chemical ecology of Antarctic marine invertebrates. Am Zool 37:329-342

McDonald PS, Jensen GC, Armstrong DA (2001) The competitive and predatory impacts of the nonindigenous crab Carcinus maenas (L.) on early benthic phase Dungeness crab Cancer magister Dana. J Exp Mar Biol Ecol 258:39-54

Modig H, Ólafsson E (1998) Responses of Baltic benthic invertebrates to hypoxic events. J Exp Mar Biol Ecol 229: 133-148

Nystrom P, Svensson O, Lardner B, Bronmark C, Graneli W

Editorial responsibility: Otto Kinne (Editor),

Oldendorf/Luhe, Germany
(2001) The influence of multiple introduced predators on a littoral pond community. Ecology 82:1023-1039

Ólafsson E, Limén H (2002) Recovery of soft-bottoms after anoxic events: Laboratory experiments with the amphipod Monoporeia affinis from the Baltic Sea. Ophelia 56:121-134

Race MS (1982) Competitive displacement and predation between introduced and native mud snails. Oecologia 54: $337-347$

Ronn C, Bonsdorff E, Nelson WG (1988) Predation as a mechanism of interference within infauna in shallow brackish water soft bottoms - experiments with an infauna predator, Nereis diversicolor (Müller). J Exp Mar Biol Ecol 116:143-157

Ross DJ, Johnson CR, Hewitt CL (2003) Variability in the impact of an introduced predator (Asterias amurensis: Asteroidea) on soft-sediment assemblages. J Exp Mar Biol Ecol 288:257-278

Ruiz GM, Fofonoff PW, Carlton JT, Wonham MJ, Hines AH (2000) Invasion of coastal marine communities in North America: apparent patterns, processes, and biases. Annu Rev Ecol Syst 31:481-531

Russell DE (1995) The diurnal vertical migration of Marenzelleria viridis (Polychaeta: Spionidae) in Chester River. Am Zool 35:115A

Schiedek D (1997) Marenzelleria viridis (Verrill, 1873) (Polychaeta), a new benthic species within European coastal waters. Some metabolic features. J Exp Mar Biol Ecol 211: 85-101

Stenroth P, Nystrom P (2003) Exotic crayfish in a brown water stream: effects on juvenile trout, invertebrates and algae. Freshw Biol 48:466-475

Stigzelius J, Laine A, Rissanen J, Andersin AB, Ilus E (1997) The introduction of Marenzelleria viridis (Polychaeta, Spionidae) into the Gulf of Finland and the Gulf of Bothnia (northern Baltic Sea). Ann Zool Fenn 34:205-212

Usio N, Konishi M, Nakano S (2001) Species displacement between an introduced and a 'vulnerable' crayfish: the role of aggressive interactions and shelter competition. Biol Invasions 3:179-185

Walton WC, MacKinnon C, Rodriguez LF, Proctor C, Ruiz GA (2002) Effect of an invasive crab upon a marine fishery: green crab, Carcinus maenas, predation upon a venerid clam, Katelysia scalarina, in Tasmania (Australia). J Exp Mar Biol Ecol 272:171-189

Wenngren J, Neideman R, Ólafsson E (2003) Juveniles seek adults over small spatial scales: trade-offs between facilitation and food-competition in the benthic amphipod Monoporeia affinis? Licentiate thesis, Stockholm University

Winkler HM, Debus L (1997) Is the polychaete Marenzelleria viridis an important food item for fish? Proc Balt Mar Biol Symp 13:147-151

Woodin SA (1991) Recruitment of infauna: positive or negative cues? Am Zool 31:797-807

Zettler ML, Bochert R, Bick A (1994) Röhrenbau und Vertikalverteilung von Marenzelleria viridis (Polychaeta: Spionidae) in einem inneren Küstengewässer der südlichen Ostsee. Rostock Meeresbiol Beitr 2:215-225

Submitted: June 18, 2003; Accepted: September 27, 2003

Proofs received from author(s): November 26, 2003 